\title{
An Assessment of Allocative Efficiency of Organic Mango Farms in Northern Ghana
}

\author{
Bunbom Edward Daadi \\ Department of Climate Change and Food Security, \\ Faculty of Agribusiness and Communication Sciences \\ University for Development Studies, Tamale, Ghana \\ Gazali Issahaku \\ Department of Climate Change and Food Security, \\ Faculty of Agribusiness and Communication Sciences \\ University for Development Studies, Tamale, Ghana \\ Joseph Amikuzuno \\ Department of Climate Change and Food Security, \\ Faculty of Agribusiness and Communication Sciences \\ University for Development Studies, Tamale Ghana
}

\begin{abstract}
Despite numerous government interventions, increasing agricultural productivity to ensure food security still remains a challenge facing Ghana's agriculture, which is largely conventional, but has a growing organic production and niche market. Since 2001, the Integrated Tamale Fruit Company has been assisting Northern Ghana's hitherto subsistence farmers to cultivate organic mango through an out-grower scheme aimed at boosting the productivity and market access, and reducing the production cost of farms in the scheme. Anecdotally, the livelihood of organic mango farmers does not seem to have improved, despite significant increases in the performance of participating farms. This study provides empirical evidence on the actual economic performance of organic mango farmers in Northern Ghana and establishes the implications of this for livelihood and empowerment in organic mango farm household by estimating input-use efficiency. By fitting a tranlog average response production function to data from 204 organic mango farms, we obtained input-use efficiency ratios of 1.83 and 1.91 for weeding expenditure incurred by group and family out-growers respectively, and ratios of 0.24 and 0.11 for organic pesticides. The results suggest that to improve their livelihood, farmers need to increase their investment in weeding and reduce that of pesticides use.
\end{abstract}

Keywords: Farm incomes, Integrated Tamale Fruit Company, Input-Use Efficiency, Organic Mango, Out-Growers

\section{INTRODUCTION}

A historical review of the food insecurity situation in Ghana from the colonial era clearly indicates that the phenomenon is more prevalent and endemic in Northern than Southern Ghana because of a lag in the evolution of yield-enhancing agricultural production and commercialization technologies (Hanson, Y. 2013). Food supply systems get so stressed that physical and/or financial access to adequate and quality food is often limited, especially in the 
off-farm season. The seasonal food insecurity usually render about $10-13 \%$ of Northern Ghana's population food-unsecured (UN , 2012). Ironically farm households, especial those who do not grow cash crops are usually the worse affected. Thus increasing smallholder farm household income became the target of agricultural reform policies, particularly Food and Agriculture Sector Development Policy (FASDEP), for the area.

Which cash crop to promote became an issue that had to be addressed because the two popular cash crops (cotton and cashew) grown in the area are facing setbacks due to falling price in the international market. Mango became the obvious choice yet challenges to market access had to be addressed to make production profitable for farmers. Production of mango, like any other crop is largely conventional in the Northern Region of Ghana having very limited local market demand for current supply volume of 40,000tons/annum(Zakari,2012 and Pay, 2009). There is however a growing niche market internationally (Pay, 2009; Obeng and Oehmke, 2012) demanding more of organically produced mangoes which attract high premium prices. Accessing this international market is critical for farmers to get good returns on their investment but that requires them being part of a supply chain that is able to take all their produce from farm gate to the international consumer markets. Thus, farmers in the Northern Region needed to organize themselves into producer based-groups in order to adopt organic technology, produce exportable organic mangoes and supply to the only international market value chain being promoted by Integrated Tamale Fruit Company (ITFC) in the area.

Adopting organic technology in producing mango as an alternative livelihood may be questioned by its critics who think it cannot be carried out on large scale, turns out lower yield than conventional and therefore becomes a threat to global food security. However, what the critics are failing to acknowledge is that numerous research findings (Varughese, 2009; Delate and Cambardella, 2004, FAO 2003, FAO, 2000 and Drinkwater, Wagoner and Sarrantonio, 1998) have refuted all these claims. Organic agriculture has proven greater yield potentials under some normal conditions and superior under all adverse weather conditions.

Contrary to critics' view, organic farms do not need scale-up before impacting world food supply because $70 \%$ of world food supply comes from small holder farmer. In addition, for many small-scale farmers, the purchase of chemical fertilizers and pesticides (inputs in conventional agriculture)is constrained by the high costs, relative to output prices, or simply by their unavailability. Also the farmers, especially in developing countries like Ghana, who buy pesticides face environmental and health hazards because they lack the capacity to use them properly or information on safe use these chemicals is simply not available. Furthermore, those who buy such inputs often do so by credit, which can push them into a cycle of debt and dependency, especially if their harvests fail. This risk is further increased because of ever increasing oil prices which affect conventional agricultural input prices directly and indirectly.

Hence, since organic farming assures increased productivity, sustainability, cost effectiveness and can conveniently be practiced by those who supply more than $2 / 3$ of worlds' food needs, its adoption by such farmers is a better alternative to addressing food security challenges even under adverse weather conditions induced by climate change.

Though international market access is the motivating factor for Integrated Tamale Fruit Company ITFC to assist farmers, since 2001, to go into the organic mango production under an out-grower scheme, the need to reduce cost, boost productivity and improve farm incomes through organic technology raises concerns about how the farmers are economically performing under the scheme. Affirming the fact that organic agriculture can assure productivity contrary to critics view, outputs from farms of family and groups under the outgrower scheme appear satisfactory and farmers reported to have had improved levels of 
revenues well over their previous earnings (UNDP, 2007), even though technical efficiency analysis of the same farms suggest that there is still room for improvement (Daadi, Issahaku and Amikuzuno, 2014). Since economic efficiency is a product of technical and allocative efficiency, this study seeks to provide empirical evidence about the latter in order to give a comprehensive view of the organic mango farms. The paper therefore applied marginal analysis on average production function to determine allocative efficiency of two categories (groups and family) of farmers under the ITFC organic mango out-grower scheme and draws implications on their economic welfare in terms of income gains.

\section{PRODUCTIVITY AND EFFICIENCY}

Production involves converting set(s) of inputs into output(s) and therefore, the amount of output obtained at the end of any production process depends on the amount of inputs applied and how these inputs are combined. While the level of input set determines scale effect (Coelli, 2005), inputs coordination affects how effective input-to-output conversion will be, considering physical quantities, economic values or both (Han, 1991). The combination of scale and input coordination (quantities and values) effects on output is referred to as productivity. It is defined, simply, as the ratio of output to input or input to output (Sartorius and Kirsten, 2004).

Productivity may be measured using empirical performance indices such as output per unit cost, output per unit time or output per unit area of production. Managers of business measure productivity in terms of earnings per share (EPS), return on investment (ROI), economic value added (EVA) or cash flow return on investment (Hashem et al, 2010).

The measures of productivity mentioned above only compare output to input but do not indicate whether the productive capacity of the input is fully utilized in producing the output or it is not possible to produce the given level of output with less of the input. More detailed evaluation of production performance is to carry out efficiency analysis, which does not only examine output from a given input, but further compares the output to what can be achieved with the given input set. This way, productivity is examined through three elements: technical efficiency, allocative efficiency and economic efficiency which together have direct effect on profitability of decision-making units (Daadi et al, 2014).

Farrell (1957)'s work on the measurement of productive efficiency of firms helped deepened economists' understanding of the concept of efficiency. Economists look at efficiency as a relationship between ends and means and when they say a situation is inefficient, it implies they could achieve the desired ends with less means, or the means employed could produce more of the desired ends with regards to value (Barnett, 2004). Thus, economic efficiency is measured by the relationship between the value of the ends and the value of the means rather than physical quantities (Heyne, 2008).This paper assesses the performance of smallholder organic mango farmers in terms of allocating their variable inputs viz. weeding expenditure and organic pesticides. Thus the remaining discussions after this section focus on allocative efficiency.

\section{ALLOCATIVE EFFICIENCY CONCEPT}

Allocative efficiency is concerned with the extent to which a farm/firm achieves a given level of output when cost-minimizing input levels are applied in the production process (Bravo-Ureta et al, 1997). It refers to the ability to choose optimum input levels at given factor prices, output level and price in production process. Optimality of inputs proportions, given their prices according to Coelli (1995), is the subject of interest when assessing firm's allocative efficiency. 
Kopp and Diewert (1982) measured allocative efficiency as the ratio of economically efficient cost to technically efficient cost.

Empirically, two approaches are commonly employed to assess allocative efficiency as noticed from the literature. These are firm-specific allocative efficiency approach and input-specific (input-use) allocative efficiency approach which measures an efficiency ratio for each of the inputs used among firms under consideration (Daadi et al, 2014).

The former is determined by estimating a minimum cost frontier for a set of data from which the efficiency estimate for each farm is derived. Estimates obtained this way are said to contain elements of technical efficiency. Thus according to Coelli et al (2005), the above are cost efficiency rather than allocative efficiency estimates. Again, some authorities think such estimates are bias and should not be combined with technical efficiency estimates to produce economic efficiency, unless a system of Cobb-Douglas production and cost functions are appropriate for the data set (Bravo-Ureta and Pinheiro, 1997).

Input-specific allocative efficiency ratios are obtained by applying the principle of marginal returns in production process whereby an input is said to be efficiently allocated if it is employed at a level that the marginal value product (MVP) is equal to marginal factor cost (Barnett, 2004;Oluwatayoet al, 2008 ; Omonona et al, 2010 and Al-hassan, 2012). The marginal factor cost at that point should equal a unit cost or price of the input in question. Input-use allocative efficiency estimates are therefore traditionally obtained by estimating a production function (average response model) for the data using OLS. This production function is then subjected to marginal analysis to obtain factor elasticities (E) as well as marginal physical products (MPPs). MPP is derived from the production function by; first, taking the derivative (E) with respect to the input. It is then multiplied by the ratio of average output to average input. The MVP is the product of MPP and output price (Py). If the price (a unit cost) of the input known as Marginal Factor Cost (MFC) is provided, an index (R) for determining allocative efficiency of the input used can be computed algebraically as follows:

$Y=f(X ; \beta)$

$$
E_{i}=\frac{\partial \ln Y}{\partial \ln X}
$$

$M P P=\left(\frac{\bar{Y}}{\bar{X}}\right) * E$

$$
M P P_{X_{i}} * P_{Y}=M V P=P_{X}
$$

If input $\mathrm{x}$ is $100 \%$ efficiently allocated then,

$$
\frac{M V P_{X}}{P_{X}}=R_{X}=1
$$

Where and are as defined above.

Otherwise, the input is either under-applied(R $>1)$ or over-applied( $R<1)$. In order to achieve full allocative efficiency in a situation where $\mathrm{R} \neq 1$, there is the need to increase or decrease the amount of inputs used. The extent of change required in the inputs' application in such cases is given by $(1-R) \times 100($ Nwaru and Iheke, 2010). 
Results from the initial trial model suggested that the Cobb-Douglas functional form was not appropriate for the data because there was significant interaction between inputs and their cross terms. Once the Cobb-Douglas production function which usually has its alternative (dual) cost function could not be applied, a system of equations as required by the first approach could not be generated. Thus, the input-specific approach to estimating allocative efficiency was adopted. Though deterministic, applying this approach on a stochastic average production function places the estimated allocative efficiency ratios between deterministic and stochastic estimates. Such ratios indicate firms' shortfall from ideal performance, extent of changes in inputs that needs to be made in order to achieve desired economic performance as well as the amount of economic gains that can be derived by becoming fully efficient.

\section{METHODOLOGY}

The study covers the ITFC's operational area of four (4) districts of the Northern Region, including Savelugu-Nanton, Kumbungu, West Manprusi and Karaga districts. The sample was drawn from a total population of 1400 organic mango out-growers with some owning infant plantations. A list of all the farmers obtained from the scheme management was used as the sampling frame to draw the sample. This was stratified into group-managed and familylymanaged farms after which, simple random sampling procedure was used to obtain a representative sample from the group-managed out-growers, whilst a census of the familylymanaged out-growers was employed because their number was small (53 out-growers).

The study used the average response production function for the empirical analysis of the data. The analytical model used to achieve the objective is presented below.

$$
\begin{aligned}
& \ln Y_{i}=\beta_{0}+\beta_{1} \ln \text { PlAge }_{i}+\beta_{2} \ln W \exp _{i}+\beta_{3} \ln P e K g_{i}+.5 \beta_{11} \ln \left(\text { PlAge }_{i}\right)^{2}+.5 \beta_{22} \ln \left(W \exp _{i}\right)^{2} \\
& +.5 \beta_{33} \ln \left(P e K g_{i}\right)^{2}+\beta_{12}\left(\ln P l A g e_{i} \cdot \ln W \exp _{i}\right)+\beta_{13}\left(\ln P l A g e_{i} \cdot \ln P e K g_{i}\right) \\
& +\beta_{23}\left(\ln W \exp _{i} \cdot \ln P e K g_{i}\right)+\left(v_{i}-u_{i}\right)
\end{aligned}
$$

Where, $Y_{-}$i is total output of mango (kg/ha), PlAge is age of plantation (years) Wexp, is weeding expenditure (Ghc/ha), PeKg is quantity of organic pesticides (kg/ha), $\beta_{-} 0$ is constant and $\beta_{-}$srepresent the coefficients of inputs PlAge,Wexp,PeKgand their second order terms respectively.

From the Equation (6) above, input elasticities (Es) and marginal physical products MPPs of weeding expenditure and organic pesticide were computed. Elasticity E (of weeding expenditure and organic pesticide are respectively given by:

$$
E_{W \exp }=\frac{\partial \ln Y}{\partial \ln W \exp }=\beta_{2}+\beta_{12} \ln P l \text { Age }+\beta_{22} \ln W \exp +\beta_{23} \ln P e K g
$$

Where, $Y$, PlAge, Wexp and PeKgare as defined earlier.

The elasticities obtained from the equations above are used to calculate marginal physical products (MPP) of the two inputs as given respectively by; 


$$
\begin{aligned}
& M P P_{W \exp }=\frac{\bar{Y}}{\bar{X}_{W \exp }} \cdot E_{W \exp } \\
& M P P_{P e K g}=\frac{\bar{Y}}{X_{P e K g}} \cdot E_{P e K g} .
\end{aligned}
$$

Where $\bar{Y}$ Yand $X$ represent the arithmetic means of mango output and each input for the farm management types respectively (Al-hassan, 2004).

Using Equations 9 and 10 together with output and input prices, marginal value product $M V P$ and marginal factor cost $M F C$ the allocative efficiency ratios $R_{i}$ for each input is derived. The rule-of-thumb is that if $R_{i}=1(M V P=M F C)$ there is full allocative efficiency for input $i$, $R_{i}>1 \rightarrow$ input $i$ is under applied and $R_{i}<1 \Rightarrow$ over-application of $i^{\text {th }}$ input. Input utilization indices $R s$ are tested by the t-test to evaluate whether they are statistically different from one (1). The extent to which out-growers need to change the utilization of the inputs in question so that full allocative efficiency is achieved is evaluated by the formula below.

$\Delta=\left(1-\mathrm{R}_{\mathrm{ij}}\right) \times 100$

Where $\Delta$ is the extent of change required, $R_{i j}$ is the allocative efficiency ratio of input $i$ for $j^{\text {th }}$ farm management type.

\section{RESULT AND DISCUSSION}

Group-managed farms are generally twice as large as family farms (Table 1). It should be noted however, that farm size as a characteristic does not indicate scale of production for a group out-grower since each group out-grower is limited to 0.4 hectares. Rather, it suggests the size of the group managing the farm. On the other hand, farm size indicates scale of production among family out-growers since an family out-grower owns 0.4 or more hectares.

\begin{tabular}{|c|c|c|c|c|c|}
\hline Variable & Unit & $\begin{array}{l}\text { Sample } \\
(\mathrm{N}=204)\end{array}$ & $\begin{array}{c}\text { Group } \\
\text { Out- } \\
\text { growers } \\
(n=151) \\
\end{array}$ & $\begin{array}{c}\text { Family Out- } \\
\text { growers } \\
(n=53)\end{array}$ & Z-value \\
\hline \multicolumn{6}{|c|}{ Socio-economic Attributes of Out-growers } \\
\hline Household size & $\begin{array}{ll}\text { No. } & \text { of } \\
\text { people }\end{array}$ & 6 & 6 & 6 & 0 \\
\hline Education & $\begin{array}{l}\text { No. of } \\
\text { years }\end{array}$ & 2 & 2 & 3 & $-2.201 * *$ \\
\hline Demonstrations & $\begin{array}{l}\text { No. } \\
\text { times }\end{array}$ & 7 & 6 & 7 & $-2.379 * *$ \\
\hline \multicolumn{6}{|c|}{ Farm Characteristics } \\
\hline Farm Size & Hectares & 4 & 4.8 & 2.8 & $3.502 * * *$ \\
\hline Plantation Age & Years & 6 & 6 & 5 & 1.031 \\
\hline \multicolumn{6}{|c|}{ Input Variables } \\
\hline Weeding & Ghana & 31 & 31 & 31 & 0 \\
\hline Expenditure/ ha & Cedis & & & & \\
\hline Organic Pesticide & $\mathrm{Kgs} / \mathrm{ha}$ & 3.5 & 3.5 & 3.75 & 0.793 \\
\hline Price of Pesticide & $\begin{array}{l}\text { Ghana } \\
\text { Cedis }\end{array}$ & 2.26 & 2.19 & 2.33 & $-1.831 *$ \\
\hline
\end{tabular}

Table1.Summary Statistics of Variables 


\section{Output Variable}

Yield/ha

$\mathrm{Kg} / \mathrm{ha}$

105

281.25 $-34.76^{* * *}$

Source: Own Data

The age of plantations is about the same across farm management types. All farms in the sample are within the first of three agronomic age groupings; developing bearers, stabilized bearers and aging bearers. This means that all farms are young and still growing; hence output is expected to increase each year, all other conditions remaining optimal.

An average group out-grower applies about 3.5 kilograms of organic pesticide per hectare which is obtained at GH\$2.199/ kg while an average family out-grower pays G\$2.33/kg and applies $3.75 \mathrm{~kg} / \mathrm{ha}$ of the same pesticide. There is however no difference between the expenditure of weeding that both categories of out-growers make.

The mean mango output per hectare of family out-growers is about three times that of group out-growers $(281.25 \mathrm{Kg}$ against $105 \mathrm{Kg}$ ). This huge difference in output can only be attributed to differing quality of management, because there is no significant difference in physical quantities of inputs (weeding expenditure and organic pesticides) used between the two outgrower types to justify the difference in output.

Table 2 presents the allocative efficiency estimates for the group- and family- managed farm types respectively.

Table 2. Average Response (OLS) by Farm Management Types

\begin{tabular}{|c|c|c|c|c|}
\hline \multirow[t]{2}{*}{ Variable } & \multicolumn{2}{|c|}{ Group } & \multicolumn{2}{|c|}{ Family } \\
\hline & Coefficient & Std error & Coefficient & $\begin{array}{l}\text { Std } \\
\text { error }\end{array}$ \\
\hline Const. & $0.971 * * *$ & 0.326 & $1.17^{* * *}$ & 0.321 \\
\hline InPIAge & $0.026^{*}$ & 0.012 & $0.075^{*}$ & $0.034 \mathrm{~S}$ \\
\hline $\ln W \exp$ & $0.146^{* *}$ & 0.063 & $0.054^{*}$ & 0.029 \\
\hline $\operatorname{lnPeKg}$ & 0.006 & 0.054 & $0.148 * * *$ & 0.023 \\
\hline $.5\left(\ln (\mathrm{PlAge})^{2}\right)$ & $2.93^{* * *}$ & 0.893 & $2.94 * * *$ & 0.86 \\
\hline $.5\left(\ln (\mathrm{Wexp})^{2}\right)$ & -0.038 & 0.137 & 0.034 & 0.102 \\
\hline $.5\left(\ln (\mathrm{PeKg})^{2}\right)$ & -0.013 & 0.027 & 0.31 & 0.371 \\
\hline lnPlAge* $\operatorname{lnWexp}$ & 0.047 & 0.126 & -0.046 & 0.102 \\
\hline InPIAge*InPeKg & -0.030 & 0.31 & -0.045 & 0.093 \\
\hline $\begin{array}{l}\ln W \exp * \ln P e K g \\
\sigma^{2}\end{array}$ & $\begin{array}{c}-0.005^{* * *} \\
\mathbf{0 . 8 3}^{* * *}\end{array}$ & $\begin{array}{l}0.002 \\
\mathbf{0 . 0 8 7}\end{array}$ & $\begin{array}{l}-0.145^{*} \\
\mathbf{0 . 8 7 * * *}\end{array}$ & 0.078 \\
\hline Log likelihood & -184.4 & & -142.03 & 0.137 \\
\hline
\end{tabular}

Age of the plantation, expenditure on weeding and its self-interaction terms of the weeding expenditure are significant variables that contribute positively to output, and for that matter, 
allocative efficiency. The quantity of pesticide used is a very significant contributor to output in the case of family but not group farms. Farmers' level of education directly affects their ability to efficiently apply technology including the use of organic pesticides (Fane, 1975, Ebong, et al, 2009 and Al-hassan, 2012). Table 1 above shows a clear difference between group and family out-growers with respect to level of education with a z-value of 2.201.Thus, it is not surprising that family out-growers are able to apply pesticides to affect yield as against group outgrowers.

The self-interaction term of plantation age contributes most by adding about 2.9 percent of total output of both group and family out-grower for every successive year of age. This could be as a result of the age bracket of the plantations in both situations (all plantations were developing bearers). Weeding expenditure positively and statistically affected yield among both out-growers; buttressing the importance of weeding within plantations. Weeding expenditure and quantity of Pest used interact to reduce output significantly, especially among group out-growers. This could be attributed to the general inefficiency in input allocation observed in both cases $(\mathrm{R}=0.24$ and $\mathrm{R}=0.11$ for group and family out-growers respectively; Table 3). In all, the function explains about $83 \%$ of the total variation in output of groups while that of family explains $87 \%$ with overall fitting efficiency ascertained by generalized log likelihood test.

From the estimated average responds functions, input elasticities (E), marginal value products (MVP), Marginal factor cost (MFC) and allocative ratios (R) of the two inputs were computed (Table 3). The next two sections discuss the results for these inputs.

The results (Table 3) reveal that allocative efficiency ratio (R) for weeding expenditure is greater than one (1) among out-growers of group and family farm management types (1.83 and 1.91 respectively).This translates into $83 \%$ and $91 \%$ allocative inefficiency respectively. Thus, farms are not weeded properly as most farms were observed to be weedy even during the harvesting season. Response from sampled out-growers suggests that group out-growers often contract out their weeding operations while family out-growers normally engage laborers' on wage basis to weed their mango farms.

With the estimated MVP's (1.83 and 1.91respectively), a Ghana cedi spent on contract weeding operation will give less returns(83\%) than a Ghana cedi spent on paying wage of a laborer for weeding (91\% return). Hence though, expenditure on weeding needs to be increased by both categories of farms, family out-growers need to do more since the average weeding expenditure is GH\$31 per hectare for both categories of farms. With the same average expenditure (GH\$31 per hectare), group out-growers should be able to increase expenditure by $\mathrm{GH} \$ 25.7(83 \%)$ that will yield total return of $\mathrm{GH} \$ 47.08$ representing $\mathrm{GH} \$ 21.35$ net increased earnings per hectare. Likewise, family out-growers can increase their expenditure by $\mathrm{GH} \$ 28.21(91 \%)$ expecting a total returns of $\mathrm{GH} \$ 53.88$ representing $\mathrm{GH} \$ 25.67$ net increased earnings. These earnings in both situations are enough to enhance household food security by financially accessing about 40 kilograms of the staple maize grain required to provide variety of local meals for an average household of 6 persons for just a fortnight.

Family out-growers again exhibit inefficiency as compared to group out-growers, with respect to organic pesticide use with efficiency ratios(R) of 0.11 and 0.24 respectively. To attain full allocative efficiency in botanical pesticide use at current unity cost of GH\$2.199 and 2.33, group and family out-growers have to reduce the use of organic pesticide by $76 \%$ and $89 \%$ respectively. That extent of reduction will yield Gh\$5.85and 7.78 of cost savings per hectare hence net returns by same amounts respectively, all other things being equal. These will 
enhance the welfare of an organic mango farm household by securing $3.9 \mathrm{kgs}$ and $5.2 \mathrm{kgs}$ of grain respectively.

Table 3: Inputs' Allocative Efficiency Analysis by Farm Management Types

\begin{tabular}{clcccc}
\hline Managements Type & Variable & MVP & MFC & $\begin{array}{c}\text { R=MVP/ } \\
\text { MFC }\end{array}$ & $\begin{array}{c}\text { \%Change } \\
\text { Required }\end{array}$ \\
Group Out-growers & Weeding Exp & 1.83 & 1 & $1.83^{* * *}$ & -83 \\
& Organic Pesticide & 0.53 & 2.199 & $0.24 * *$ & +76 \\
Family Out-growers & Weeding Exp & 1.91 & 1 & $1.91 * * *$ & -91 \\
& Organic Pesticide & 0.26 & 2.33 & $0.11^{* * *}$ & +89 \\
\hline
\end{tabular}

Note: ${ }^{* * *}$ and ${ }^{* *}$ means statistically different form 1 at .01 and .05 significance level. (-) implies increased use is needed and $(+)$ implies reduction is needed

Source: Own data

\section{CONCLUSION}

The results of the study indicates that sampled out-growers poorly allocate the two main inputs (weeding expenditure and organic pesticide) under the prevailing prices, but group out-growers exhibit more efficiency. In order to attain full allocative efficiency in weeding expenses, group out-growers need to increase their weeding expenditure by $83 \%$ whilst family out-growers must increase theirs by $91 \%$. For organic pesticides, group out-growers have to reduce its use by $76 \%$ whilst family out-growers need to do so by $89 \%$.

With these allocative efficiency indices, it becomes necessary that out-growers, especially the family, weed their farms more frequently. With improved farm sanitation, there will less need to spray farms because incidence of pest infestation will reduce, thus optimizing the expenditure they make on organic pesticide. Alternatively, farmers will also have to integrate their farm business a step backward by investing in botanical pesticide extraction themselves. They can also establish a trusted relationship with pesticide suppliers through Organic Mango Out-growers Association (OMOA) so that they can negotiate for lower prices in the long-run. Farmers adopting these changes are expected to increases earnings from organic mango by an average amount of $\mathrm{GH} \$ 23.5$ per hectare from weeding and $\mathrm{GH} \$ 4.5$ from organic pesticides. With such earning they will be better off in terms food security for at least a fortnight.

\section{References}

Al-hassan Seidu (2012). "Technical Efficiency in Smallholder Paddy Farms in Ghana: an Analysis Based on Different Farming Systems and Gender". Journal of Economics and Sustainable Development. 3(5): 91-98.

Barnett (2004). "Problems” Quarterly Journal of Australian Economis 7(1): 95-104.

Bravo-Ureta, Boris E. and Laszlo Rieger (1991). “Dairy Farm Efficiency Measurement

Using Stochastic Frontiers and Neoclassical Duality "American Journal of Agriculture Economics 73(2): 421-28.

Bravo-Ureta and Pinheiro (1997). "Technical, Economic and Allocative Efficiency in

Peasant Farming: Evidence from the Dominican Republic" The Developing Economies 35 (1):48-67.

Coelli T. J. (1995). “Recent Developments in Frontier Modeling and Efficiency

Measurement", Australian Journal of Agricultural Economics, 39 (3): 219-245. 
Coelli T. J.Rao, D.S.P. O'Donnell C.J. and Battese G.E. (2005).An Introduction to Efficiency and Productivity Analysis, 2nd Edition, Springer: 41-61.

Daadi B. E., Issahaku G. and Amikuzuno J. (2014). "Technical Efficiency Analysis of Organic Mango Out-Grower Farm Management Types: The Case of Integrated Tamale Fruit Company (ITFC) Out-Growers in Northern Region" African Journal of Agricultural Economics and Rural Development, 2 (3): 129-137.

Delate K and Cambardella CA.(2004). "Organic production: Agro-ecosystem performance during transition to certified organic grain production". Agronomy Journal 2004, 96, 1288-98.

Drinkwater, L. E., Wagoner, P. \& Sarrantonio, M. (1998). “Legume-based cropping systems have reduced carbon and nitrogen losses." Nature 396, pp262 - 265

Fane, G (1975). "Education and the Managerial Efficiency of Farmers". The Review of Economics and Statistics, Vol. 57, No. 4 (Nov., 1975), pp. 452-461.

FAO (2000) "Food Safety and Quality as Affected by Organic Farming" Twenty Second FAO Regional Conference for Europe, Porto, Portugal, 24-28 July 2000 Agenda Item 10.1,

FAO (2003), Organic Agriculture: The Challenge of Sustaining Food Production while Enhancing Biodiversity" The United Nations, Rome, Italy

Farrell, Michael J. (1957). “The Measurement of Production Efficiency” Journal of the

Royal Statistics Society, Series A, 120(3) 253-290.

Han K.H. (1991). "A productivity measurement of activities at the micro level

“Management Accounting Research, 2(4): 249-261.

Hanson Nyantakyi-Frimpong (2013) Food Security in Northern Ghana: Issues in Historical and Contemporary Contexts. Africa Portal Backgrounder (62).

Heyne Paul (2008). “Efficiency” The concise Encyclopedia of Economics: 1157-1166.

Hashem N. Mahdi M. and Mohammad M. (2010).“Efficiency Measurement of Enterprises Using the Financial Variables of Performance Assessment and Data Envelopment Analysis” Applied Mathematical Sciences, 4(37):1843 - 1854.

Jan Heisenberg, Joseph A. Yaro (2006). "An assessment of the extent and causes of food insecurity in Northern Ghana using a livelihood vulnerability framework", 67(1):41-55.

Kopp Raymond J. and W. Erwin Diewert (1982)."The Decomposition of Frontier Cost Functions Deviations into Measures of Technical and Allocative Efficiency" Journal of Econometrics 19 (3): 319-31.

Ministry of Food and Agriculture (2007). "Food and Agricultural Sector Development

Policy II (FASDEP)" Government of Ghana Policy Document: 24-29.

Office of the Auditor General of Canada (2007).“Understanding Efficiency”Auditing of efficiency. http://www.oagbvg.gc.ca, Accessed on 07/11/2011.

Obeng A. M. and Oehmke J. F. (2009).“Trade and Investment Program for a Competitive Export Economy in Ghana: A Synthesis of Findings" Policy Brief, pp3-5.

Oluwatayo, I. B., Sekumade A. B. and Adesoji S.A. (2008). "Resources Use Efficiency ofMaize Farmers in Rural Nigeria: Evidence from Ekiti State”, World Journal of Agricultural Science, 4, 91-99.

Omonona, B.T., Egbetokun, O.A. and Akanbi A.T. (2010).“Farmers Resource - Use and

Technical Efficiency in Cowpea Production in Nigeria", Economic Analysis \&Policy, 40(1): 87-95.

Elen(2009). "The Market for Organic and Fair-Trade Mangoes and Pineapples: Increasing incomes and food security of small farmers in West and Central Africa through exports of organic and fair-trade tropical products" Study prepared in the framework of FAO project GCP/RAF/404/GER: 5-11

Sartorius Kurt and J Kirsten (2004). "The Cost Efficiency of Small Farm Inclusion in

Agribusiness Supply Chains." South African Journal of Accounting Research, 18(1): 87-113. 
Daadi, B. E., Issahaku, G., \& Amikuzuno, J. (2015). An Assesssment of Allocative Efficiency of Organic Mango Farms in Northern Ghana. Archives of Business Research, 3(2), 114-124.

United Nations (2012). “Ghana Comprehensive Food Security and Vulnerability Analysis (CFSVA)” World Food Program: 19-31.

United Nations Development Program (2007).“Organic Mangoes Improving Livelihoods for the Poor: Case Study of Integrated Tamale Fruit Company” Bulletin-Growing Inclusive Markets.www.growinginclusivemarkets.org 28/09/2010.

USAID (2009). “Ghana Assessing Economic Benefits: The Case of Banana, Mango, and Rice”, Ghana Moongate Associates, portfolio Economics series (1): 24-31. http://www.moongateassociates.com/Portfolio.html $13 / 05 / 2014$.

Varughese, Kuruvilla (2009). “Organic farming practices for rice under diversified cropping systems in humid tropics."The Proceedings of the International Plant Nutrition Colloquium XVI: pp4

Wiessman, S. R. (1990) 'Structural Adjustment in Africa: Insights from the Experiences of Ghana and Senegal', World Development, 18(12): 1621-1634.

Yifu Lin, J. (1991), "Education and Innovation Adoption in Agriculture: Evidence from Hybrid Rice in China”, American Journal of Agricultural Economics, Vol. 73, No. 3, pp. 713-723.

Zakari, A. K. (2012). “Ghana National Mango Study": 30-32. Online

athttp://www.intracen.org/uploadedFiles/intracenorg/Content/About_ITC/Where_are_we_working/Mu 